\title{
The Effect of Inventory Turnover Period on the Profitability of Listed Nigerian Conglomerate Companies
}

\author{
Sunusi Garba ${ }^{1}$, Boudiab Mourad ${ }^{2} \&$ Muhammad Adamu Chamo $^{3}$ \\ ${ }^{1}$ Department of Accounting, Federal University Dutse, Jigawa, Nigeria \\ ${ }^{2}$ Tunku Intan Safinaz School of Accountancy (TISSA), Universiti Utara Malaysia, Malaysia \\ ${ }^{3}$ Department of Accounting, Bayero University Kano, Nigeria \\ Correspondence: Mourad Boudiab, Tunku Intan Safinaz School of Accountancy (TISSA), Universiti Utara Malaysia, \\ Malaysia.
}

Received: September 6, 2019

Accepted: December 31, 2019

Online Published: March 17, 2020

doi:10.5430/ijfr.v11n2p287

URL: https://doi.org/10.5430/ijfr.v11n2p287

\begin{abstract}
This study analyses the association concerning inventory turnover management and Nigerian conglomerate firms' profitability. The study is used a historical panel data analysis. Data were generated from the yearly accounts of listed firms from 2007 to 2016. The population of the study consists of six conglomerate firms registered on the Nigerian Stock Exchange. Feasible generalized least square (FGLS) regression was utilized as tools of analysis in the study. The findings establish that inventory turnover management affects Nigerian conglomerate companies' profitability inversely associated to the profitability of the listed conglomerate firms in Nigeria. The study suggests that there must be regular stock-taking to determine eventually, the slothful stocks to dodge over venture in such stocks (if any). Furthermore, if there is no high demand for the goods the inventory needs to be reduce that are obsolescence. Management should also implement an extraordinary inventory management measures.
\end{abstract}

Keywords: ITP, profitability, conglomerate companies

\section{Introduction}

Inventory is a critical composition of firms' current assets. The stocks of Industrial businesses habitually comprise: work-in-progress, raw materials, or finished products. Generally, to enhance working capital it is important to balance between having inventory for sales and keeping the as less inventory as possible. The company loses out income if there are fewer stocks, and the company cannot meet the demand of the client. At the same time, the company should be careful about holding too much inventory to avoid an opportunity cost as well as obsolescence. Therefore, inventory management is among the greatest confusing chores for managers, as they must try to cut the inventory handing expenses and also need reduce the cash conversion cycle. Reducing a stock close to zero level may cause deficiency of raw material for production or finished product in demand. Such condition must be expensive for any firm because of the incomes they would lose (Maness \& Zietlow, 2005). Hence, good inventory control is always necessary and essential in managing working capital (Van, Hung, Van, \& Xuan, 2019). Additionally, in Nigeria high costs of production as a result of poor infrastructure; the shortage of infrastructure has been one of the major threats to the profit maximization of many conglomerates firms. Therefore, especially in the conglomerate or manufacturing firms, the inventory turnover management is very important factor to be considered.

Furthermore, empirical findings on the relationship between inventory turnover and firm profitability are mixed. Whereas some postulated a positive relationship, which is any increase in stock turnover period will increase the firm's revenues (Gill, Biger \& Mathur, 2010; Rimo \& Panbunyuen, 2010; Soekhoe, 2012; Warnes, 2013). On the other hand, some claimed a negative relationship, which is any increase in stock turnover period will reduce the firm's returns (Alipour, 2011; Ali, Rahman, \& Obaid, 2017; Lamptey, Frimpong, \& Morrison 2017; Lee, Song, \& Lee 2009; Panigrahi, 2013; Sharif \& Islam, 2018; Usama, 2012). Moreover, globally there are limited studies that explored the role of inventory management on profitability of conglomerate firms. Therefore, this study examines the impact of inventory turnover management on the Nigerian conglomerate firm's profitability. After that, this article is outlined as follows: subsequent section reviews related literature on issues related to the subject matter; it is tailed by the methodology; the next section centred on data analysis and interpretation of findings, and the final section 
concludes the paper and suggests recommendations.

\section{Literature Review on Inventory Management and Profitability}

Inventories are operational working capital which can be optimized and influenced by firm activities. In conglomerate business, inventory is always one of the most valuable assets of a firm. Therefore, good inventory control is always necessary and essential in managing working capital (Van, Hung, Van, \& Xuan, 2019). Moreover, growth in production level increases firm's inventories. However, building unnecessary working capital in due course increases adverse effects on investors' wealth (Gill, Mand, Obradovich, \& Mathur, 2019). Therefore, an optimum Inventory Management strategy is essential for the firm to maximise its profitability.

Empirically, many researchers have studied the impact of Inventory Management on Profitability. The findings of these studies reviewed reveal the diverse outcome. For instance, Lee, et al. (2009) found that days of inventory increases in a manufacturing firm may result in better performance. They suggested keeping enough inventories for smooth flow of business and not to lose customers and sales. Likewise, Mathuva (2009) found a significant positive relationship between profits and inventory turnover days. From the developed American economy, Nobanee and AlHajjar (2009) found that inventory conversion period had a significant positive impact on returns. Moreover, Rimo and Panbunyuen (2010) findings show a significant positive link relating to profitability and inventory days. Furthermore, Soekhoe (2012), using 70 Dutch companies showed a positive significant effect of inventory conversion period on profitability which means that the more inventory the firm has the more benefits it gets. Likewise, Warnes (2013) using the data of listed conglomerate companies at Pakistan from 2007-2011 found that return on assets are significantly and positively impacted by the number of days inventory. In Nigeria, Samson, Josiah, Yemisi, and Erekpitan (2012) using Nigerian Small and Medium Sized Firms covering the year 2009 found that managers can create value by increasing their firms' inventories turnover.

However, Eizadinia and Taki (2010) show that high inventory leads to lower profitability of the companies. There is also evidence from Alipour (2011) found a negative significant effect of inventory turnover on profitability. Likewise, Hayajneh and Yassine (2011) show a significant negative association between profitability and average inventory transformation period. Similarly, Pouraghajan, Rekabdarkolaei, and Shafie (2013) using the list of automotive companies registered in the Tehran Stock Exchange between 2006 and 2010 found a significant negative relationship between inventory turnover and ROA. Furthermore, Iqbal and Zhuquan (2015) found a significant negative relationship between ITP and profitability. It is recommended that managers can improve the profitability and value of their firms by reducing inventory turnover in days. Moreover, Ali, et al. (2017) shows a negative effect of inventory turnover in days on firms' sales. Moreover, Lamptey, et al. (2017) inventory turnover days were significantly and negatively related to performance. Likewise, Sharif and Islam (2018) stated that the number of days in inventory has a negative effect on corporate profitability. Thus, based on prior studies it can be hypothesized that:

$\mathrm{H}_{0}$ : High Inventory turnover has a significant negative relationship with profitability in listed Nigeria conglomerate companies.

\section{Methodology}

This study is based on historical panel data analysis. Therefore, ex-post facto research design is suitable for the study where the variables of the study were not classified as the event of the study has already occurred. The study covered the period from 2007 to 2016. The six listed conglomerate companies on the Nigerian Stock Exchange constitute the population of this study. Their annual reports are the primary sources of data for this study. Table 1 presents the six companies that make up the population and sample of the study:

Table 1. Population of the study

\begin{tabular}{llll}
\hline S/N. & Company & Listed on & Paid-Up Capital (N) \\
\hline 1 & A.G Leventis Nigeria Plc & 1978 & $1,323,645,000.00$ \\
\hline 2 & Chellarams Plc & 1977 & $361,463,000.00$ \\
\hline 3 & John Holt Plc & 1974 & $195,000,000.00$ \\
\hline 4 & SCOA Nigeria Plc & 1977 & $324,737,000.00$ \\
\hline 5 & Transnational Corporation of Nigeria Plc & 2006 & $12,906,999,000.00$ \\
\hline 6 & UAC of Nigeria Plc & 1974 & $800,360,000.00$
\end{tabular}

Source: NSE Factbook 2016 
Table 2 below presents the descriptions, acronyms, measurements and sources of the study variables.

Table 2. Descriptive of variable measurement

\begin{tabular}{llll}
\hline $\begin{array}{l}\text { Variables } \\
\text { Description }\end{array}$ & Acronym & Formula & Source \\
\hline $\begin{array}{l}\text { Return on Net } \\
\text { Assets }\end{array}$ & ROA & $\begin{array}{l}\text { The ratio of Net Income to } \\
\text { Total Asset }\end{array}$ & $\begin{array}{l}\text { (Afza \& Nazir, 2009; Al-Absy, Ku Ismail, \& } \\
\text { Chandren, 2019; Falope \& Ajilore, 2009). }\end{array}$ \\
\hline $\begin{array}{l}\text { Inventory } \\
\text { Turnover Period }\end{array}$ & ITP & $\begin{array}{l}\text { Average inventory divided Cost } \\
\text { of Sales multiplies by 365 days }\end{array}$ & \begin{tabular}{l} 
(Raheman \& Nasr, 2007). \\
\hline Firm Size
\end{tabular} \\
FS & Natural logarithm of total asset & $\begin{array}{l}\text { (Al-Absy, Ku Ismail, \& Chandren, 2018; Dong } \\
\text { 2 Su, 2010; Gill et al., 2010; Raheman \& Nasr, } \\
\text { 2007). }\end{array}$ \\
\hline Leverage & LEV & $\begin{array}{l}\text { Proportion of a fixed asset to } \\
\text { total assets }\end{array}$ & $\begin{array}{l}\text { (Dong \& Su, 2010; Gill et al., 2010; Raheman \& } \\
\text { Nasr, 2007). }\end{array}$ \\
\hline
\end{tabular}

The functional relationships among these variables are therefore be defined as:

$$
\mathrm{ROA}_{\mathrm{it}}=f(\mathrm{ITP}, \mathrm{SZ}, \mathrm{LEV})_{\mathrm{it}}+\epsilon_{\mathrm{it}}
$$

From this general form of the regression equation, a model is designed to test hypothesis developed. This model is consistent with the works of Garcia-Teruel and Martinez-Solano (2007), Falope and Ajilore (2009) and Hayajne and Yassine (2011).

$$
\mathrm{ROA}_{\mathrm{it}}=\alpha_{0}+\alpha_{1} \mathrm{ITP}_{\mathrm{it}}+\alpha_{2} \mathrm{SZ}_{\mathrm{it}}+\alpha_{3} \mathrm{LEV}_{\mathrm{it}}+\epsilon_{\mathrm{it}}
$$

\section{Data Analysis and Discussion of Results}

Table 3 provides summary statistics for the variables of the study. All the variables were computed from the annual reports of the sampled companies.

Table 3. Descriptive statistics of the variables

\begin{tabular}{llllll}
\hline Variable & Obs & Mean & Std. Dev. & Min & Max \\
\hline ROA & 60 & 3.9170 & 8.5023 & -16.7700 & 37.9900 \\
\hline ITP & 60 & 124.0332 & 84.7397 & 1.6400 & 369.3800 \\
\hline SZ & 60 & 16.7318 & 1.1111 & 14.8500 & 19.2500 \\
\hline LEV & 60 & 0.5892 & 0.2566 & 0.1500 & 1.4900 \\
\hline
\end{tabular}

Table 3 discloses that the ROA of the conglomerate companies has an average of 3.92\% ranged from a minimum return of $16.77 \%$ to a maximum of $37.99 \%$, this signify that for everyone Naira worth of net investment, the worst loss for the industry was N16.77 and the best earning was a maximum of N37.99 kobo. Industrial firms have an average earning of $3.92 \%$ on its net investment with a high degree of risk, as returns varied at both sides of the scale have $8.50 \%$. Despite the fact that some industrial firms could shorten this range to 1 to 2 days only, others were not able to turn inventories into sales before 369 days.

In order to analyze the nature of the correlation between the independent and the dependent variables and to make sure if there is multi-collinearity because of the correlation among variables, Correlation analysis assesses the inter-relationship and association between variables. The Pearson correlation analysis is used here to assess the relationship between the variables of ITP and profitability Table 4 is computed for this purpose. The correlation matrix in Table 4 provides some insights into which of the independent variables are related to the dependent variable $R O A$. 
Table 4. Correlation coefficients of the variables

\begin{tabular}{llllll}
\hline & ROA & ITP & SZ & LEV \\
\hline ROA & 1.0000 & & & 1.05 \\
\hline ITP & -0.0986 & 1.0000 & 1.0000 & 1.10 \\
\hline SZ & -0.0952 & $-0.2165^{*}$ & -0.1998 & 1.0000 & 1.04 \\
\hline LEV & $-0.4656^{* * *}$ & -0.0081 & & \\
\hline
\end{tabular}

From the above Table 4, the values on the diagonal are all 1.000, indicating that each variable is perfectly correlated with itself. The highest correlations with ROA is for LEV (-0.4656) which is negative, which implies there is lack of multicollinearity with ROA and all variables. Similarly, the correlations in the explanatory variables ascertain absence of multicollinearity as the maximum correlation coefficient is that of ITP and LEV with a positive value of -0.2165. Regarding the nature of the correlation between the dependent and the independent variables, the relationship between Return On Assets and ITP shows a negative and insignificant amounted to only -0.0986 which is less than $10 \%$, which implies as ITP reduces by less than $9.86 \%$ ROA will increase by the same percentage. Similarly, from the Table 4, the VIF range from 1.04 to 1.100 indicates absence of Multi-collinearity.

Aiming to establish the effect of ITP in the management of working capital on the profitability of conglomerate firms in Nigeria, the regression equation, $\mathrm{ROA}_{\mathrm{it}}=\alpha_{0}+\alpha_{1} \mathrm{ITP}_{\mathrm{it}}+\alpha_{2} \mathrm{SZ}_{\mathrm{it}}+\alpha_{3} \mathrm{LEV}_{\mathrm{it}}+\epsilon_{\mathrm{it}}$, model is run. Base on the Breusch and Pagan Lagrangian multiplier (BPML) test of 1.000 OLS is recommended as the most appropriate regression for the dataset. Pesaran's test provides an evidence of absence of cross-sectional independence in the dataset, however, heteroskedasticity and first-order autocorrelation (AR1) is found in which it necessitated the use of FGLS to solve these problems as the $\mathrm{N}<\mathrm{T}$ as recommended by Hoechle (2007). Using FGLS the regression result of the Impact of ITP on Profitability is evaluated from the model summary as presented in Table 5.

Table 5. Regression results of the impact of ITP on profitability using FGLS

\begin{tabular}{lllll}
\hline ROA & Coef. & Std. Err. & $\mathrm{z}$ & $\mathrm{P}>\mathrm{z}$ \\
\hline ITP & -0.0153 & 0.0113 & -1.3500 & 0.0875 \\
\hline SZ & -1.7658 & 0.8800 & -2.0100 & 0.0225 \\
\hline LEV & -16.9972 & 3.7205 & -4.5700 & 0.0000 \\
\hline Cons & 45.3763 & 15.7256 & 2.8900 & 0.0020 \\
\hline R-square & 0.2362 & & \\
\hline Prob $>$ F & 0.0000 & & & \\
\hline BPML test & 1.0000 & & \\
\hline Hausman specification test & 0.0611 & & \\
\hline Link test & 0.1130 & & \\
\hline Modified Wald test heteroskedasticity & 0.0000 & & \\
\hline First-order autocorrelation & 0.0160 & & \\
\hline Pesaran's test of cross-sectional independence & 0.7725 & & \\
\hline
\end{tabular}

The outcome of Table 5 showed an R2 of $27.59 \%$ indicating that the variables considered in the model account for about $27.59 \%$ change in the dependent variables that is ROA, while the remaining of the change is because of other variables not addressed by this model. Likewise, the P-Value of 0.0000 , as well as Link test of 0.1130 , proved the model to be fit. From the same result in Table 5, using one-tail test p-value of ITP 0.0875 is higher than 0.05 , and for a null hypothesis to be rejected the p-value has to be lower than 0.05 (for a $95 \%$ confidence level) or an alpha of 0.10 (for a $90 \%$ confidence level), thus the ITP has significant influence on the dependent variable (ROA) as the p-value of 0.0875 is lower than 0.10. This is consistent with Alipour (2011); Lee, et al. (2009); Panigrahi (2013); Usama (2012) findings that there is an inverse relationship between the high inventory turnover and profitability. However, 
oppose with Ali (2011); Rimo and Panbunyuen (2010); Soekhoe (2012); and Warnes (2013) that attest a positive relationship.

In the overall considering both correlation and regression results, the result of correlation between ROA and ITP show a negative 0.0986 which implies as ITP reduces by less than $10 \%$ ROA will increase by the same percentage and on the other hand both $\mathrm{z}$-value and p-value reveal a significant negative relationship between ITP and ROA, thus it will be deduced that relationship between the ITP and profitability of listed conglomerate firms in Nigeria is significant and negative.

\section{Conclusion and Recommendations}

From the above discussions of the research findings it can be concluded that ITP is negatively and significantly related to the profitability of the listed conglomerate companies in Nigeria. This is because, if a firm keeps a high level of stock with liberal credit policy, the firm's sales are expected to growth; this will ultimately increase the firm's profitability. Nevertheless, the inventory days an increase is always attached with additional storing cost. Therefore, a regular stock checking should be done frequently to evade over-relying on dawdling moving stocks (if any).

Also conglomerates firms should emphasize to increase sales to increase inventory turnover to achieve maintainable competitive advantage through managing inventory to optimal level so as to maximize profitability. So, this article proves that, an efficient inventory management can increase profitability of all firms in conglomerates industry of Nigeria. This study is limited to the sample of Nigerian Stock Exchange listed conglomerates firms only. Future studies should investigate beyond the Nigerian Stock Exchange listed conglomerates firms.

\section{References}

Afza, T., \& Nazir, M. (2009). Impact of aggressive working capital management policy on firms' profitability. The IUP Journal of Applied Finance, 15(8), 20-30.

Al-Absy, M. S. M., Ku Ismail, K. N. I., \& Chandren, S. (2018). Board Chairmen's Involvement in the Nomination and Remuneration Committees and Earnings Management. Australasian Accounting, Business and Finance Journal, 12(4), 60-76. https://doi.org/10.14453/aabfj.v12i4.5

Al-Absy, M. S. M., Ku Ismail, K. N. I., \& Chandren, S. (2019). Corporate governance mechanisms and family directives: aggressive or conservative in earnings' management?. Academy of Accounting and Financial Studies Journal, 23(1), 1-9.

Ali, S., Rahman, A., \& Obaid, Z. (2017). Can working capital cycle or cash conversion cycle be factored in economic performance of Pakistani corporate firms?. JHSS, $X X V(1)$.

Alipour, M. (2011). Working capital management and corporate profitability: Evidence from Iran. World Applied Sciences Journal, 12(7), 1093-1099.

Dong, H. P., \& Su, J. (2010). The relationship between working capital management and profitability: A Vietnam case. International Research Journal of Finance and Economics, 49, 59-67.

Eizadinia, N., \& Taki, A. (2010). The survey of the effects of working capital management on the profitability of listed companies in Tehran stock exchange. Quarterly of Financial Accounting, 2(5), 120-139.

Falope, O. I., \& Ajilore, O. T. (2009). Working capital management and corporate profitability: Evidence from panel data analysis of selected quoted companies in Nigeria. Research Journal of Business Management, 3(3), 73-84. https://doi.org/10.3923/rjbm.2009.73.84

Garcia-Teruel, P. J., \& Martinez-Solano, P. (2007). Effects of working capital management on SME profitability. International Journal of Managerial Finance, 3(2), 164-177. https://doi.org/10.1108/17439130710738718

Gill, A., Biger, N., \& Mathur, N. (2010). The relationship between working capital management and profitability: Evidence from the United States. Retrieved June 12, 2013, from http://astonjournals.com/bej

Gill, A., Mand, H. S., Obradovich, J., \& Mathur, N. (2019). The impact of working capital management on the decision of production firms about the amount of dividends. International. Journal of Business and Globalisation, 22(3), 372-388. https://doi.org/10.1504/IJBG.2019.099300

Hayajneh, O. S., \& Yassine, F. L. A. (2011). The impact of working capital efficiency on profitability - An empirical analysis on Jordanian manufacturing firms. International Research Journal of Finance and Economics, 66, $67-76$. 
Hoechle, D. (2007). Robust standard errors for panel regressions with cross-sectional dependence. Stata Journal, 7(3), 281. https://doi.org/10.1177/1536867X0700700301

Iqbal, A., \& Zhuquan, W. (2015). Working capital management and profitability evidence from firms listed on Karachi stock exchange. International Journal of Business and Management, 10(2), 231-235. https://doi.org/10.5539/ijbm.v10n2p231

Lamptey, L. L., Frimpong, K., \& Morrison, A. B. (2017). Empirical study on the influence of working capital management on performance of SMEs in a developing economy. British Journal of Economics, Management \& Trade, 17(4), 1-10. https://doi.org/10.9734/BJEMT/2017/33579

Lee, H. J., Song, S. H., \& Lee, H. J. (2009). Correlation between SCM and finance performances: Evidence from Korean companies.

Maness, T. S., \& Zietlow, J. T. (2005). Short-Term Financial Management (3rd ed.). Ohio: South-Western/Thomson Learning.

Mathuva, D. (2009). The Influence of Working Capital Management Components on Corporate Profitability: A Survey on Kenyan Listed Firms. Research Journal of Business Management, 3, 1-11. https://doi.org/10.3923/rjbm.2010.1.11

Nobanee, H., \& AlHajjar, M. (2009). Working capital management, operating cash flow and corporate performance. Retrieved June 12, 2013, from http://ssrn.com/abstract=1471236

Panigrahi, A. K. (2013). Cash conversion cycle and firms' profitability - A study of cement manufacturing companies of India. International Journal of Current Research, 5(6), 1484-1488.

Pouraghajan, A., Rekabdarkolaei, E. A., \& Shafie, M. (2013). Investigation the effects of working capital management and capital structure on profitability and return on assets (case study: A selection from the automotive companies in Iran). Journal of Basic and Applied Scientific Research, 3(4), 847-854.

Raheman, A., \& Nasr, M. (2007). Working capital management and profitability - Case of Pakistani firms. International Review of Business Research Papers, 3(1), 279-300.

Rimo, A., \& Panbunyuen, P. (2010). The Effect of Company Characteristics on Working Capital Management: A Quantitative Study of Swedish Listed Companies. Student UMEÅ School of Business Spring Semester Master Thesis, Two-Year, 15 HP.

Samson, A. A., Josiah, M., Yemisi, B., \& Erekpitan, I. O. (2012). The impact of working capital management on the profitability of small and medium scale enterprises in Nigeria. Research Journal of Business Management, 6(2), 61-69. https://doi.org/10.3923/rjbm.2012.61.69

Sharif, M. A., \& Islam, M. R. (2018). Working capital management a measurement tool for profitability: A study on pharmaceutical industry in Bangladesh. Journal of Finance and Accounting, 6(1), 1-10. https://doi.org/10.11648/j.jfa.20180601.11

Soekhoe, S. G. (2012). The effects of working capital management on the profitability of Dutch listed firms. MSc Business Administrative Thesis, University of Twente School of Management and Governance.

Usama, M. (2012). Working capital management and its effect on firm's profitability and liquidity: In other food sector of (KSE) Karachi stock exchange. Arabian Journal of Business and Management Review (OMAN Chapter), 1(12), 62-73. https://doi.org/10.12816/0002232

Van, H. T. T., Hung, D. N., Van, V. T. T., \& Xuan , N. T. (2019). Managing optimal working capital and corporate performance: Evidence from Vietnam. Asian Economic and Financial Review, 9(9), 977-993. https://doi.org/10.18488/journal.aefr.2019.99.977.993

Warnes, S. (2013). Impact of working capital management on firm's profitability: Empirical evidence from cement sector (a case study of Pakistani firms). American Journal of Governance and Politics, 3(2), 46-55. 